\title{
Assessment of multifunctional activity of bioactive peptides derived from fermented milk by specific Lactobacillus plantarum strains
}

\author{
J. E. Aguilar-Toalá, ${ }^{*}$ L. Santiago-López, ${ }^{*}$ C. M. Peres,† C. Peres, † H. S. Garcia,§ B. Vallejo-Cordoba, \\ A. F. González-Córdova, ${ }^{*}$ and A. Hernández-Mendoza*1 \\ *Centro de Investigación en Alimentación y Desarrollo A.C. (CIAD), Hermosillo, Sonora 83304, Mexico \\ †Instituto de Tecnologia Química e Biológica, Universidade Nova de Lisboa, P-2780-157 Oeiras, Portugal \\ łlnstituto Nacional de Inestigação Agraria e Veternária (INIAV), Instituto Português (IP), Estação Agrnómica Nacional (EAN), \\ P-2780-157 Oeiras, Portugal \\ §Unidad de Investigación y Desarrollo en Alimentos (UNIDA), Instituto Tecnológico de Veracruz, Veracruz 91897, Mexico
}

\section{ABSTRACT}

Milk-derived bioactive peptides with a single activity (e.g., antioxidant, immunomodulatory, or antimicrobial) have been previously well documented; however, few studies describe multifunctional bioactive peptides, which may be preferred over single-activity peptides, as they can simultaneously trigger, modulate, or inhibit multiple physiological pathways. Hence, the aim of this study was to assess the anti-inflammatory, antihemolytic, antioxidant, antimutagenic, and antimicrobial activities of crude extracts (CE) and peptide fractions ( $<3$ and $3-10 \mathrm{kDa}$ ) obtained from fermented milks with specific Lactobacillus plantarum strains. Overall, CE showed higher activity than both peptide fractions $(<3$ and $3-10 \mathrm{kDa}$ ) in most of the activities assessed. Furthermore, activity of $<3 \mathrm{kDa}$ was generally higher, or at least equal, to the 3 to $10 \mathrm{kDa}$ peptide fractions. In particular, L. plantarum 55 crude extract or their fractions showed the higher anti-inflammatory (723.68-1,759.43 $\mu \mathrm{g} / \mathrm{mL}$ of diclofenac sodium equivalents), antihemolytic (36.65-74.45\% of inhibition), and antioxidant activity [282.8-362.3 $\mu \mathrm{mol}$ of Trolox (Sigma-Aldrich, St. Louis, MO) equivalents]. These results provide valuable evidence of multifunctional role of peptides derived of fermented milk by the action of specific L. plantarum strains. Thus, they may be considered for the development of biotechnological products to be used to reduce the risk of disease or to enhance a certain physiological function.

Key words: milk-derived peptide, Lactobacillus, peptide fraction, multifunctional peptides

Received August 8, 2016.

Accepted September 27, 2016.

${ }^{1}$ Corresponding author: ahernandez@ciad.mx

\section{INTRODUCTION}

Fermented milk products, which contain different biologically active components, have been widely associated with nutrition and health benefits (Ebringer et al., 2008). In recent years in particular, scientific interest has focused on bioactive peptides encrypted on milk proteins, as increasing evidence indicates that these peptides might constitute a valuable tool against different human diseases. For instance, in vitro and in vivo studies have shown the possible role of bioactive peptides in cancer prevention (Roy et al., 2002; Eliassen et al., 2006), in blood pressure management (Seppo et al., 2003; Townsend et al., 2004; Cadée et al., 2007; Pripp, 2008; Li et al., 2011), and in treating type 2 diabetes (Manders et al., 2006; Jakubowicz and Froy, 2013), as well as to improve sleep in healthy elderly people (Yamamura et al., 2009).

These health benefits have been associated with the numerous biological activities of bioactive peptides, including antioxidant, opioid, antihypertensive, antithrombotic, antimicrobial, immunomodulatory, and antitumor, among others (Matar et al., 2003; Sah et al., 2014). Peptides with more than one activity are preferred over single-activity peptides because they can simultaneously trigger, modulate, or inhibit multiple physiological pathways. Within the body systems, it is observed that bioactivity in one area often results in a beneficial effect in another (Hartmann and Meisel, 2007; Sistla, 2013; Agyei et al., 2015). In this sense, milk-derived multifunctional peptides, such as lactoferrin-derived peptides, casein-derived phosphopeptides, and chymotryptic peptides, obtained by enzymatic hydrolysis using pepsin, trypsin, and chymotrypsin, respectively, have been previously reported (Srinivas and Prakash 2010; Sistla, 2013; Mandal et al., 2014; Agyei et al., 2015).

Conversely, the release of different single-activity peptides from milk proteins via microbial proteolysis 
is well documented (FitzGerald and Murray 2006; Korhonen, 2009), but few studies describe the multifunctional activity of milk-derived peptides obtained by microbial fermentation (Qian et al., 2011; Elfahri et al., 2014). Therefore, the aim of our study was to assess the anti-inflammatory, antihemolytic, antioxidant, antimutagenic, and antimicrobial activities of crude extracts and peptide fractions $(<3$ and $3-10 \mathrm{kDa}$ ) obtained from fermented milks with specific Lactobacillus plantarum strains.

\section{MATERIALS AND METHODS}

\section{Bacterial Strains and Culture Propagation}

Four Lactobacillus plantarum strains (coded as 26, 27, 55 , and 56, respectively) were obtained from the Food Microbial Technology Laboratory collection (ITQB, Oeiras, Portugal). These strains were previously isolated from Portuguese raw ewe milk semisoft cheeses, identified to species level via multiplex PCR assay using $r e c A$ gene-derived primers, and assessed for probiotics features [A. Hernández-Mendoza, C. M. Peres, M. Alves (Instituto de Tecnologia Quimica e Biologica, Universidade Nova de Lisboa), A. F. Gónzalez-Córdova, B. Vallejo-Cordoba, C. Peres, and F. X. Malcata (Laboratory for Engineering of Processes, Environment, Biotechnology and Energy, Lisbon, Portugal), unpublished data]. Cultures were activated by successive subculturing in de Man, Rogosa, Sharpe broth (Difco, Le Pont de Claix, France) with $1 \%$ inoculations and incubation at $37^{\circ} \mathrm{C}$ for 10,18 , or $24 \mathrm{~h}$. After the last incubation period, cultures were centrifuged $(3,600 \times g, 10 \mathrm{~min}$, $\left.10^{\circ} \mathrm{C}\right)$, washed twice with PBS $(\mathrm{pH} 7.2,0.1 \mathrm{~N})$, and suspended in PBS to an optical density of 0.50 at 600 $\mathrm{nm}$, which corresponded to $\sim 10^{8} \mathrm{cfu} / \mathrm{mL}$.

\section{Fermented Milk and Preparation of Water-Soluble Extract and Fractions}

Nonfat dry milk (Organic Valley USDA Organic grade A, La Farge, WI) was reconstituted (10\%, wt/ vol), sterilized $\left(110^{\circ} \mathrm{C}, 10 \mathrm{~min}\right)$, inoculated $(2 \% \mathrm{vol} / \mathrm{vol})$ with different bacteria suspended in PBS, and then incubated at $37^{\circ} \mathrm{C}$ for $48 \mathrm{~h}$. Subsequently, the samples of fermented milk were adjusted to $\mathrm{pH} 4.6$ with $0.1 \mathrm{~N} \mathrm{HCl}$ (Donkor et al., 2007; Virtanen et al., 2007; Sah et al., 2014). Trichloroacetic acid (0.85\%) was added (2.5 mL) to $5 \mathrm{~mL}$ of fermented milk and crude extracts (CE) were separated by centrifugation $(3,500 \times g, 45 \mathrm{~min}$, $\left.10^{\circ} \mathrm{C}\right)$. The CE from fermented milks were fractionated by ultrafiltration using a 10-kDa cutoff membrane (Ultracel Amicon Ultrafiltration Discs; Millipore, Billerica, $\mathrm{MA}$ ), and then $10-\mathrm{kDa}$ permeates ware further frac- tionated using a 3-kDa cutoff membrane (Millipore). The CE, retentate $(3-10 \mathrm{kDa}$ fractions), and permeate $(<3-\mathrm{kDa}$ fractions) were sterilized with syringe filter with a $0.22-\mu \mathrm{m}$ pore size (Millipore) and stored frozen $\left(-20^{\circ} \mathrm{C}\right)$ for subsequent analysis.

\section{Total Protein Concentration}

The total protein concentration was estimated in both CE and its fractions by a modified Lowry's method (Virtanen et al., 2007) using the DC Protein Assay kit (Bio-Rad Laboratories, Hercules, CA). Bovine serum albumin was used as standard. Prior to each assay, protein concentration of samples (CE or its fractions) was adjusted by simple dilution (using a dilution factor method based on ratios) with PBS to reach a concentration of $1.2 \mathrm{mg} / \mathrm{mL}$ (the minimum protein concentration found in the samples).

\section{Antihemolytic Activity Assay}

It has been reported that temperatures over $40^{\circ} \mathrm{C}$ cause thermal hemolysis of erythrocytes (SowemimoCoker, 2002). Thus, well-known medical conditions (e.g., viral infections, cancer, thyrotoxicosis, gout) associated with temperature increase above normal range (fever, also termed pyrexia) are sufficient to induce erythrocyte hemolysis by affecting the membrane skeletal dynamics, which lead to membrane bilayer permeabilization (Gershfeld and Murayama, 1988). With this in mind, thermal hemolysis of human erythrocytes provides a useful cellular model with biological and medical importance (Tanev-Ivanov, 2014). Therefore, the antihemolytic activity was determined according to Shinde et al. (1999) and Rani et al. (2014). For that, $2 \mathrm{~mL}$ of fresh human blood from 3 healthy volunteers were collected into EDTA-blood collection tubes. The blood tubes were then centrifuged $(2,500 \times g, 5 \mathrm{~min}$, $\left.4^{\circ} \mathrm{C}\right)$ and the supernatant was removed. The isolated red blood cells were washed 3 times with an isotonic $\mathrm{NaCl}$ solution $(0.9 \%)$ by resuspension and centrifugation. The washed cells were reconstituted at $10 \%$ (vol/ vol) with respect to the original blood volume with isotonic solution.

Then an aliquot $(250 \mu \mathrm{L})$ of either test samples (CE or its fractions) or isotonic solution (control) was mixed with $250 \mu \mathrm{L}$ of red blood cells suspension. Next, heatinduced hemolysis was conducted by incubating in a water bath at $56^{\circ} \mathrm{C}$ for $30 \mathrm{~min}$. After the incubation period, the tubes were cooled in cold water $\left(4^{\circ} \mathrm{C}\right)$, centrifuged $\left(2,500 \times g, 5 \mathrm{~min}, 4^{\circ} \mathrm{C}\right)$, and absorbance of the supernatants was recorded at $540 \mathrm{~nm}$. The percentage of inhibition of hemolysis was calculated by the equation 
Inhibition $(\%)=[(\mathrm{A}-\mathrm{B}) / \mathrm{A}] \times 100$,

where $\mathrm{A}$ is the absorbance of control and $\mathrm{B}$ the absorbance of supernatant sample.

\section{Antimutagenic Activity Assay}

It has been postulated that mutagenesis plays an important role in both the initiation phase and the progression phase of carcinogenesis (Dixon and Kopras, 2004). Hence, the use of inhibitors of mutagenesis may be an effective tool for preventing human cancer and other genetic diseases (Sarac, 2015). In this regard, many methods have been explored to screen for antimutagenic compounds (e.g., phenolics, gallic acids, cysteine); Ames test is a widely used biological assay with real significance in detecting potentially antimutagenic agents (Mortelmans and Zeiger, 2000; Słoczyńska et al., 2014). Consequently, a direct-acting mutagen, sodium azide (Sigma-Aldrich, St. Louis, MO) dissolved in Milli-Q water (Millipore, Bedford, MD) at a final concentration of $0.01 \mu \mathrm{g} / \mathrm{mL}$, and Salmonella enterica serovar Typhimurium ATCC 29629 (TA 1535) were used for the antimutagenic test, applying the preincubation method as previously described by Espeche Turbay et al. (2012) and Sah et al. (2014) with modifications. Salmonella Typhimurium TA 1535 cells were activated by 2 transfers in nutrient broth (BD Difco, Sparks, MD), supplemented with biotin $(3 \mu M)$ and histidine $(260 \mu \mathrm{M})$, and static incubation at $37^{\circ} \mathrm{C}$ for 48 and $24 \mathrm{~h}$, respectively. Cultures were harvested by centrifugation $\left(3,600 \times g, 10 \mathrm{~min}, 10^{\circ} \mathrm{C}\right)$, washed twice in PBS, and resuspended until an optical density at 540 $\mathrm{nm}$ of 0.50 was attained, corresponding to $10^{8} \mathrm{cfu} / \mathrm{mL}$. Thereafter, $100 \mu \mathrm{L}$ of each CE or fractions being tested were mixed in glass tap tubes with $100 \mu \mathrm{L}$ of sodium azide, $500 \mu \mathrm{L}$ of PBS (100 mM, pH 7.4), and $100 \mu \mathrm{L}$ of Salmonella Typhimurium TA 1535 cells suspension. The mixtures were then preincubated at $37^{\circ} \mathrm{C}$ for 20 min. After incubation, $2 \mathrm{~mL}$ of sterile molten top agar containing L-histidine $(0.05 \mathrm{mM})$, D-biotin $(0.05 \mathrm{mM})$, $\mathrm{NaCl}(0.5 \%)$, and agar $(0.6 \%)$ were added. The resulting mixtures were poured over the surface of a minimal glucose agar medium. After the plates were incubated $\left(37^{\circ} \mathrm{C}, 48 \mathrm{~h}\right)$, the number of colonies that reversed the $\mathrm{His}^{-}$gene into the $\mathrm{His}^{+}$gene (total $\mathrm{His}^{+}$revertant colonies), which are the only ones capable to grow on this medium, were manually counted. The antimutagenic activity was expressed as the percentage inhibition of mutagenesis as

$$
\% \text { Inhibition }=[(\mathrm{A}-\mathrm{B}) /(\mathrm{A}-\mathrm{C})] \times 100,
$$

where $\mathrm{B}$ is the number of $\mathrm{His}^{+}$revertant colonies/plates induced by the sample plus mutagen; $\mathrm{A}$ is the number of $\mathrm{His}^{+}$revertant colonies per plate induced by mutagen in the absence of a sample (positive control); and $\mathrm{C}$ is the number of spontaneous $\mathrm{His}^{+}$revertant colonies in the absence of mutagen (negative control).

\section{Anti-Inflammatory Activity Test}

A marked intra- and extracellular protein-denaturing process occurs during the degenerative and necrotic stages of inflammation (Seidler and Yeargans, 2002; Chatterjee et al., 2012). Therefore, agents that can prevent protein denaturation, particularly natural substances normally present in food, may be considered as rational adjuvants for the treatment of inflammation (Saso and Silvestrini, 2001; Williams et al., 2008; Manukumar and Umesha, 2015). Thus, in vitro antiinflammatory activity was determined by the albumininhibition denaturation method according to Chandra et al. (2012) with minor modifications. The reaction mixture consisted of $25 \mu \mathrm{L}$ of egg albumin (from fresh hen eggs), $350 \mu \mathrm{L}$ of PBS (pH 7.2, $0.1 M$ ), and $250 \mu \mathrm{L}$ of either test samples (CE or fractions) or PBS (control). The mixtures were preincubated at $37^{\circ} \mathrm{C}$ for $15 \mathrm{~min}$ and then denaturation was induced by keeping the reaction mixtures at $70^{\circ} \mathrm{C}$ for $5 \mathrm{~min}$. After cooling in ice during 5 min, the optical density at $600 \mathrm{~nm}$ was recorded using a SpectraMax M3 microplate reader (Molecular Devices, Sunnyvale, CA). A 5-point $(1,111,555.5,277.7,138.8$, and $69.4 \mu \mathrm{g} / \mathrm{mL}$ ) standard curve was prepared using sodium diclofenac (DS; Docril, BIOMEP Laboratories, Naucalpan de Juárez, Mexico) as reference drug and treated similar to test samples. The results were expressed as micrograms per milliliter of DS equivalents.

\section{In Vitro Antioxidant Activity Assessment}

Antioxidants have the ability to neutralize reactive oxygen species, either by direct reduction via electron transfer or by radical quenching via $\mathrm{H}$-atom transfer, resulting in more stable species to counteract oxidative stress and its subsequent cascade of cellular, DNA, and tissue damage (Prior et al., 2005).

Radical Antioxidant Activity. The 2,2'-azinobis(3ethylbenzothiazoline)-6-sulphonic acid (ABTS) cation radical (Sigma-Aldrich) was used to evaluate antioxidant activity of test samples (CE or its fractions) using the method described by Re et al. (1999). To produce ABTS radical cations, a $7 \mathrm{mmol} / \mathrm{L}$ ABTS stock solution was reacted with $2.45 \mathrm{~m} M$ potassium persulfate (Sigma-Aldrich). The mixture was kept in the dark for $16 \mathrm{~h}$ at room temperature. The ABTS radical solution 
was then diluted with PBS $(5 \mathrm{~m} M$, $\mathrm{pH} 7.2)$ to reach an optical density at $734 \mathrm{~nm}$ of 0.70 . Next, $200 \mu \mathrm{L}$ of ABTS diluted solution was mixed with $5 \mu \mathrm{L}$ of each $\mathrm{CE}$ or fractions being tested and the optical density at $734 \mathrm{~nm}$ was recorded after 7 min with a SpectraMax M3 microplate reader. Trolox (6-hydroxy-2,3,7,8-tetramethylchroman-2-carboxylic acid; Sigma-Aldrich) was used as a standard to prepare a reference curve (0 to $500 \mu M$ in PBS) to compare those readings obtained by the samples. The results were expressed as micromoles of Trolox equivalents.

Determination of Oxygen Radical Absorbance Capacity. The oxygen radical absorbance capacity (ORAC) method was performed following the methodology reported by Ou et al. (2001) and Prior et al. (2005) using fluorescein as the probe. An aliquot of $50 \mu \mathrm{L}$ of fluorescein $(78 \mathrm{n} M)$ plus $50 \mu \mathrm{L}$ of either test sample (CE or fractions), PBS (control), or standard (Trolox) were placed in the respective well of a microplate. Next, $25 \mu \mathrm{L}(221 \mathrm{nM})$ of the peroxyl radical initiator 2,2'-azobis(2-amidinopropane) dihydrochloride were added to all wells of the microplate. The microplate was then shaken ( $5 \mathrm{~s})$, and fluorescence was recorded every minute for $80 \mathrm{~min}$, with shaking prior each reading, in a SpectraMax M3 microplate reader at excitation of $485 \mathrm{~nm}$ and emission of $535 \mathrm{~nm}$.

Data compilation and calculations were performed in a Microsoft Excel (Microsoft Corp., Redmond, WA) spreadsheet. Sample curves were normalized with respect to the control curve. From the normalized curves, the area under the fluorescence decay curve (AUC) were calculated as

$$
\mathrm{AUC}=1+\sum_{i=1}^{i=80} f_{i} / f_{0}
$$

where $f_{0}$ is the initial fluorescence reading at 0 min and $f_{i}$ is the fluorescence reading after $80 \mathrm{~min}$. The net AUC corresponding to a sample was calculated by subtracting the AUC corresponding to the control. Regression equations between net AUC and Trolox concentration were calculated for all the samples. The results were expressed as Trolox equivalents per milliliter of sample using a calibration curve in a concentration range of 0 to $500 \mu \mathrm{mol}$ of Trolox equivalents.

\section{Antimicrobial Activity}

The rapid increase of antibiotic-resistant bacteria emphasizes the necessity to search for new alternatives to circumvent the proliferation of such resistant bacteria (López-Meza et al., 2015). In this regard, many researchers have paid attention to antimicrobial peptides released from milk, which are regarded as nontoxic for mammalian cells because they are derived from a harmless source (Benkerroum, 2010). Likewise, they have been shown to inhibit a broad spectrum of targeted microorganism of health or spoilage significance, occasionally even more effective than current synthetic antibiotics (Benkerroum, 2010); therefore, it has been considered that milk-derived antimicrobial peptides possess an undeniable potential for use in feed and medical industries.

To assess the antimicrobial activity of either CE or fractions, the micro-titer plate assay was carried out according to Dasari et al. (2014), with modifications. Namely, a 14-h-old culture of each target bacteria (i.e., Staphylococcus aureus ATCC 29213, Escherichia coli ATCC 25922, Salmonella Typhimurium 14028, Salmonella choleraesuis ssp. choleraesuis serovar Choleraesuis 10708, and Listeria innocua 33090) was harvested by centrifugation $\left(3,600 \times g, 10 \mathrm{~min}, 10^{\circ} \mathrm{C}\right)$, washed twice with PBS, and resuspended with brain heart infusion broth (BD Difco) to an optical density at $600 \mathrm{~nm}$ of $0.5\left(\sim 10^{8} \mathrm{cfu} / \mathrm{mL}\right)$. Then, $100 \mu \mathrm{L}$ of either CE or PBS (control) was mixed with $100 \mu \mathrm{L}$ of each target bacterial suspension in a 96-microwell plate. The plates were then incubated at $37^{\circ} \mathrm{C}$ for $24 \mathrm{~h}$. After the incubation period, optical density at $600 \mathrm{~nm}$ was recorded using a SpectraMax M3 microplate reader. The survival of target bacteria was calculated following the equation

$\%$ of survival $=[$ (optical density value of sample

with extract or fraction/optical density value

$$
\text { of target bacteria) } \times 100] \text {. }
$$

Additionally, CE with the highest antimicrobial activity was selected and either adjusted to $\mathrm{pH} 6.8$ (Mariam et al., 2014) or treated for $2 \mathrm{~h}$ with $1 \mathrm{mg} / \mathrm{mL}$ (final concentration) of proteinase K or trypsin (Sigma-Aldrich; Albano et al., 2007). The test for antimicrobial activity was then performed as described above.

In a parallel experiment, fractions of selected $\mathrm{CE}$ were also assessed on antimicrobial activity as described before. Additionally, membrane damage of target bacteria (L. innocua), previously treated with fractions of selected $\mathrm{CE}$, was assessed by using a double simultaneous staining with membrane-impairment red fluorescent nucleic acid dye (propidium iodide, $1 \mathrm{mg} /$ $\mathrm{mL}$ ) and fluorescent dye carboxyfluorescein diacetate succinimidyl ester $(50 \mu M)$. Samples were incubated at $37^{\circ} \mathrm{C}$ for $30 \mathrm{~min}$. Bacteria treated with PBS instead of fractions was used as control. Labeled bacteria were then visualized using an Axioskope A1 fluorescence microscope (Carl Zeiss, Jena, Germany) equipped with a filter set 09 (FITC LP Ex. BP 450-490 BS. FT 510 Em. 
LP 515; Carl Zeiss) and a filter set 20 (Rhodamin F Ex. BP 546/12, BS FT 560, EM BP 575-640; Carl Zeiss) to identify membrane-compromised bacteria (inactive cells). The image acquisition was performed using the Zeiss Axionvision 4.8.3 software and the $100 \times$ immersion objective (NA 1.3, PlanNeoFluar, Carl Zeiss).

\section{Statistical Analysis}

Each experiment was repeated 3 times and all tests were run in triplicate for each experiment. The statistical analysis of experimental data was performed by oneway ANOVA using a statistical package NCSS, 2007 (NCSS Statistical software, Kaysville, UT). Significant differences were detected $(P<0.05)$ by Tukey-Kramer tests or Student's $t$-test.

\section{RESULTS AND DISCUSSION}

\section{Antihemolytic Activity}

Our results (Table 1) show that all strains evaluated were able to produce peptides with antihemolytic activity in a strain-dependent manner. Overall, CE exhibited significantly $(P<0.05)$ higher antihemolytic activity than both ultrafiltered fractions $(<3$ and $3-10 \mathrm{kDa})$; namely CE from L. plantarum 26 and 55 fermented milks those with significantly $(P<0.05)$ higher mean antihemolytic activity (57.87 and $74.45 \%$, respectively). Conversely, 3 to $10 \mathrm{kDa}$ fractions from L. plantarum 27 and 55 fermented milks showed significantly $(P<$ $0.05)$ higher mean antihemolytic activity (40.68 and $58.84 \%$, respectively) than $<3-\mathrm{kDa}$ fractions ( 22.50 and $36.65 \%$, respectively), whereas no statistical difference $(P>0.05)$ was observed on fractions from L. plantarum 56 -fermented milks.

The possible mechanisms underlying the antihemolytic activity of water-soluble extracts and fractions from fermented milks are currently not known. Several studies have shown that some compounds, including AA and peptides, exhibit thermal protection of erythrocytes by acting at the plasma membrane level (Da
Silva et al., 1994; Epand et al., 1994; Pei et al., 2007). Thus, it is reasonable to believe that bioactive peptides from fermented milk extracts could be responsible for hemolysis prevention by building a surface coating on erythrocytes that would repair pores in the membrane caused by elevated temperature.

\section{Antimutagenic Activity}

Our results (Table 1) showed that CE exhibited an overall significantly $(P<0.05)$ higher antimutagenic activity (from 73 to $93 \%$ ) than peptide fractions (from 44 to $70 \%$ ). The CE obtained from L. plantarum 27 -fermented milk had significantly $(P<0.05)$ higher mean antimutagenic activity (93.5\%) than other CE assessed, but no significant differences $(P>0.05)$ were observed among $<3$ and 3 to $10 \mathrm{kDa}$ peptide fractions, except for L. plantarum 56-fermented milk fractions.

In related works, fermented milk products have exhibited antimutagenic activity toward different mutagenic agents. For instance, Hosoda et al. (1992) investigated the antimutagenic effect of cultured milk with different lactic acid bacteria on the mutagenicity of N-methyl-N'-nitro-N-nitrosoguanidine using Salmonella Typhimurium TA 100 as an indicator strain. Each cultured milk sample displayed its characteristic antimutagenic effect, with observed inhibition values as high as 77\%. Espeche Turbay et al. (2012) also evaluated the capability of $\alpha$ - and $\beta$-CN hydrolysates, released by Lactobacillus delbrueckii ssp. lactis CRL 581 from milk proteins, to suppress the mutagenesis of a direct-acting mutagen 4NQO on Salmonella Typhimurium TA98 and TA100. Those authors observed a $4 \%$ inhibition for the

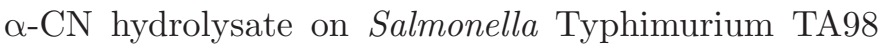
and 3 and $12 \%$ inhibition for the $\beta$-CN hydrolysate on the TA98 and TA100 strains, respectively. Similarly, Sah et al. (2014) reported mutagenic inhibition activity of sodium azide, ranging from 15.87 to $26.35 \%$, by a crude peptide extract from yogurt. Thus, our findings suggest that the antimutagenic activity registered may be attributable to milk protein-derived peptides released during fermentation. Even though the protec-

Table 1. Antihemolytic and antimutagenic activity of crude extracts (CE) and peptide fractions $(<3$ and $3-10 \mathrm{kDa})$ of fermented milk with Lactobacillus plantarum strains; data are average $( \pm \mathrm{SD})$ of triplicate samples, obtained in 3 independent assays

\begin{tabular}{|c|c|c|c|c|c|c|}
\hline \multirow[b]{2}{*}{ Strain } & \multicolumn{3}{|c|}{ Antihemolytic activity, inhibition (\%) } & \multicolumn{3}{|c|}{ Antimutagenic activity, inhibition (\%) } \\
\hline & $\mathrm{CE}$ & $<3 \mathrm{kDa}$ & $3-10 \mathrm{kDa}$ & $\mathrm{CE}$ & $<3 \mathrm{kDa}$ & $3-10 \mathrm{kDa}$ \\
\hline 26 & $57.87 \pm 4.39^{\mathrm{c}, \mathrm{A}}$ & $37.47 \pm 4.77^{\mathrm{b}, \mathrm{B}}$ & $15.95 \pm 1.70^{\mathrm{a}, \mathrm{C}}$ & $73.1 \pm 4.93^{\mathrm{a}, \mathrm{A}}$ & $58.88 \pm 0.99^{\mathrm{b}, \mathrm{B}}$ & $55.74 \pm 2.41^{\mathrm{a}, \mathrm{B}}$ \\
\hline 27 & $20.24 \pm 3.60^{\mathrm{a}, \mathrm{A}}$ & $22.50 \pm 8.77^{\mathrm{a}, \mathrm{A}}$ & $40.68 \pm 5.10^{\mathrm{b}, \mathrm{B}}$ & $93.5 \pm 1.78^{\mathrm{c}, \mathrm{A}}$ & $64.18 \pm 2.82^{\mathrm{b}, \mathrm{B}}$ & $70.82 \pm 2.63^{\mathrm{b}, \mathrm{B}}$ \\
\hline 55 & $74.45 \pm 12.48^{\mathrm{c}, \mathrm{A}}$ & $36.65 \pm 2.87^{\mathrm{b}, \mathrm{B}}$ & $58.84 \pm 2.83^{\mathrm{c}, \mathrm{C}}$ & $81.9 \pm 6.75^{\mathrm{ab}, \mathrm{A}}$ & $53.21 \pm 2.08^{\mathrm{a}, \mathrm{B}}$ & $58.52 \pm 1.04^{\mathrm{a}, \mathrm{B}}$ \\
\hline 56 & $35.19 \pm 1.57^{\mathrm{b}, \mathrm{A}}$ & $25.99 \pm 3.70^{\mathrm{a}, \mathrm{B}}$ & $24.4 \pm 1.58^{\mathrm{a}, \mathrm{B}}$ & $84.9 \pm 7.20^{\mathrm{b}, \mathrm{A}}$ & $44.17 \pm 5.91^{\mathrm{a}, \mathrm{B}}$ & $55.26 \pm 1.44^{\mathrm{a}, \mathrm{C}}$ \\
\hline
\end{tabular}

${ }^{\mathrm{a}-\mathrm{c} C o l u m n s}$ with common lowercase letters indicate no significant differences among different strains for the same sample $(P<0.05)$.

${ }^{\mathrm{A}-\mathrm{C}}$ Rows with common uppercase letters indicate no significant differences among samplers for the same strain $(P<0.05)$. 
tive effect is not entirely well understood, it has been reported that some milk proteins, peptides or sulfurcontaining AA (e.g., cysteine) may act through multiple mechanisms to provide partial or full protection against diverse mutagens. One mechanism is related to the direct interaction, by physical binding or chemical interaction, between the milk protein-derived antimutagenic compound and a mutagen before it induces DNA damage. A second mechanism entails preventing mutagen compounds from reaching or reacting with critical target sites (i.e., DNA; van Boekel et al., 1993; Liu et al., 2005; Słoczyńska et al., 2014).

\section{Anti-Inflammatory Activity}

The CE and peptide fractions evaluated here were effective, to different extents, in inhibiting heat-induced albumin denaturation (Figure 1). The CE showed activity in the range of 559.61 to $1,759.43 \mu \mathrm{g} / \mathrm{mL}$ of $\mathrm{DS}$ equivalents, with $L$. plantarum $55 \mathrm{CE}$ having higher $(P<0.05)$ anti-inflammatory activity followed by $L$. plantarum $26 \mathrm{CE}$. Conversely, $<3$-kDa fractions showed higher $(P<0.05)$ anti-inflammatory activity than 3 to $10 \mathrm{kDa}$ fractions $(1,299.2$ and $569.9 \mu \mathrm{g} / \mathrm{mL} \mathrm{DS}$, respectively). Among the $<3-\mathrm{kDa}$ fractions, those from $L$. plantarum 56- and 55-fermented milks exhibited higher $(2,112.3$ and $1,631.8 \mu \mathrm{g} / \mathrm{mL}$ of $\mathrm{DS}$, respectively) activ-

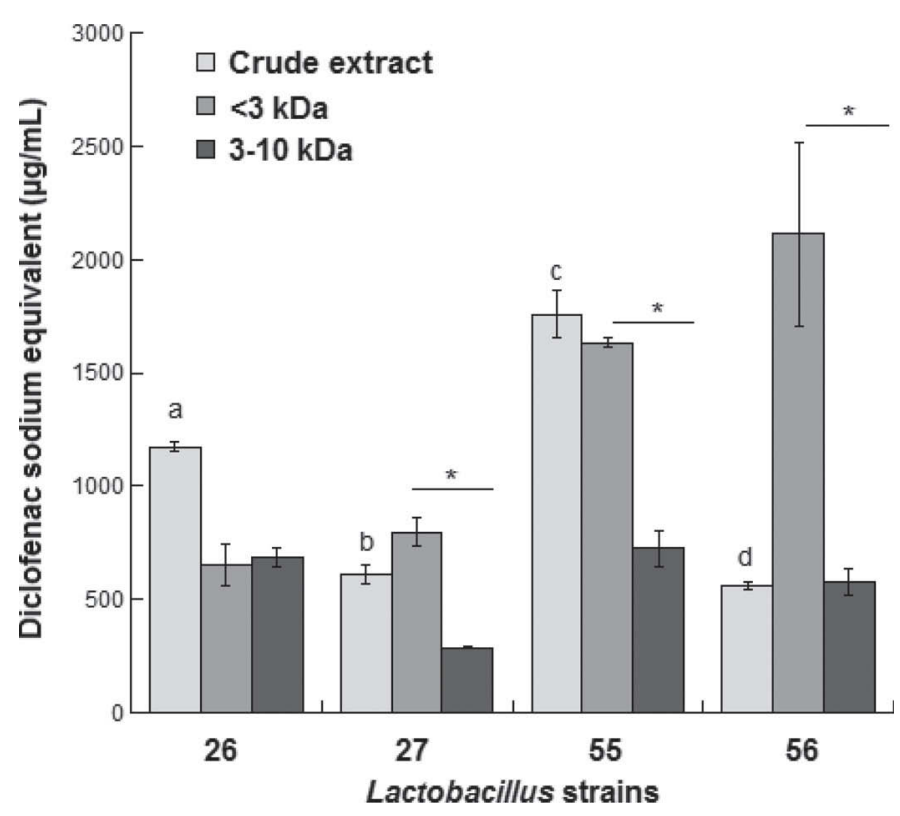

Figure 1. Anti-inflammatory activity of crude extracts (CE) and peptide fractions $(<3$ and $3-10 \mathrm{kDa})$ of fermented milk by specific Lactobacillus strains. Different letters $(\mathrm{a}-\mathrm{d})$ on bars show statistical differences between $\mathrm{CE}(P<0.05)$, whereas an asterisk $\left(^{*}\right)$ indicates statistical differences $(P<0.05)$ between fractions for the same strain. Data are average $( \pm \mathrm{SD})$ of triplicate samples, obtained in 3 independent assays. ity $(P<0.05)$. In a related work (Joshi et al., 2016), the anti-inflammatory activity of peptides derived from visceral mass of gastropod mollusk by enzymatic hydrolysis (using trypsin, alkalase, and pepsin) was determined. Data demonstrated that $3 \mathrm{~h}$ of tryptic hydrolysis showed the highest inhibition $(34.85 \pm 0.55 \%)$ of albumin denaturation (Joshi et al., 2016). Hence, our results imply that milk-derived peptides could be a promising agent against inflammatory diseases. Considering that several anti-inflammatory drugs (Mizushima and Kobayashi 1968; Grant et al., 1970) and natural active constituents (Chandra et al., 2012; Khan et al., 2015) inhibit thermally induced protein denaturation, our results clearly suggest that anti-inflammatory activity of extract or fractions found may be attributed to the presence of peptides released during milk fermentation by different Lactobacillus strains. Although the mechanism of this protection is not clear, it has been reported that some AA stabilize proteins by specifically binding to them, thus providing a shield-like protection against denaturants such as heat, extreme $\mathrm{pH}$ values, and oxidative stress (Kendrick et al., 2002; Obruca et al., 2015).

\section{Antioxidant Activity}

The antioxidant activity of $\mathrm{CE}$ and peptide fractions from fermented milks was determined by ABTS and ORAC methods (Figure 2). Results indicated that peptides presents in $\mathrm{CE}$ and peptide fractions from fermented milks have the ability to neutralize reactive oxygen species, either by direct reduction via electron transfer or by radical quenching via $\mathrm{H}$-atom transfer, resulting in more stable species (Prior et al., 2005). Antioxidant capacity was strain-specific; overall, CE from fermented milks showed greater antioxidant capacity (ranging from $\sim 100$ to $270 \mu \mathrm{mol} / \mathrm{L}$ of Trolox equivalents by ABTS assay, and from $\sim 250$ to $350 \mu$ mol of Trolox equivalents by ORAC assay) than peptide fractions. Particularly, CE from L. plantarum 55-fermented milk recorded the highest $(P<0.05)$ antioxidant capacity by both methods, whereas peptide fractions from $L$. plantarum 56-fermented milks exhibited the lowest $(P$ $<0.05)$ antioxidant capacity.

The antioxidant capacity of milks fermented by different lactic acid bacteria has been previously assessed. For instance, Hernández-Ledesma et al. (2005) reported a moderate ABTS radical scavenging capacity (0.1 and $0.26 \mu \mathrm{g}$ of Trolox equivalents) in commercial fermented milks. Virtanen et al. (2007) demonstrated radical scavenging activity by ABTS, with an inhibition rate in the range of 3 to $53 \%$, of whey fractions obtained after fermentation of milk using 25 different lactic acid bacteria. Similarly, the antioxidant activity 

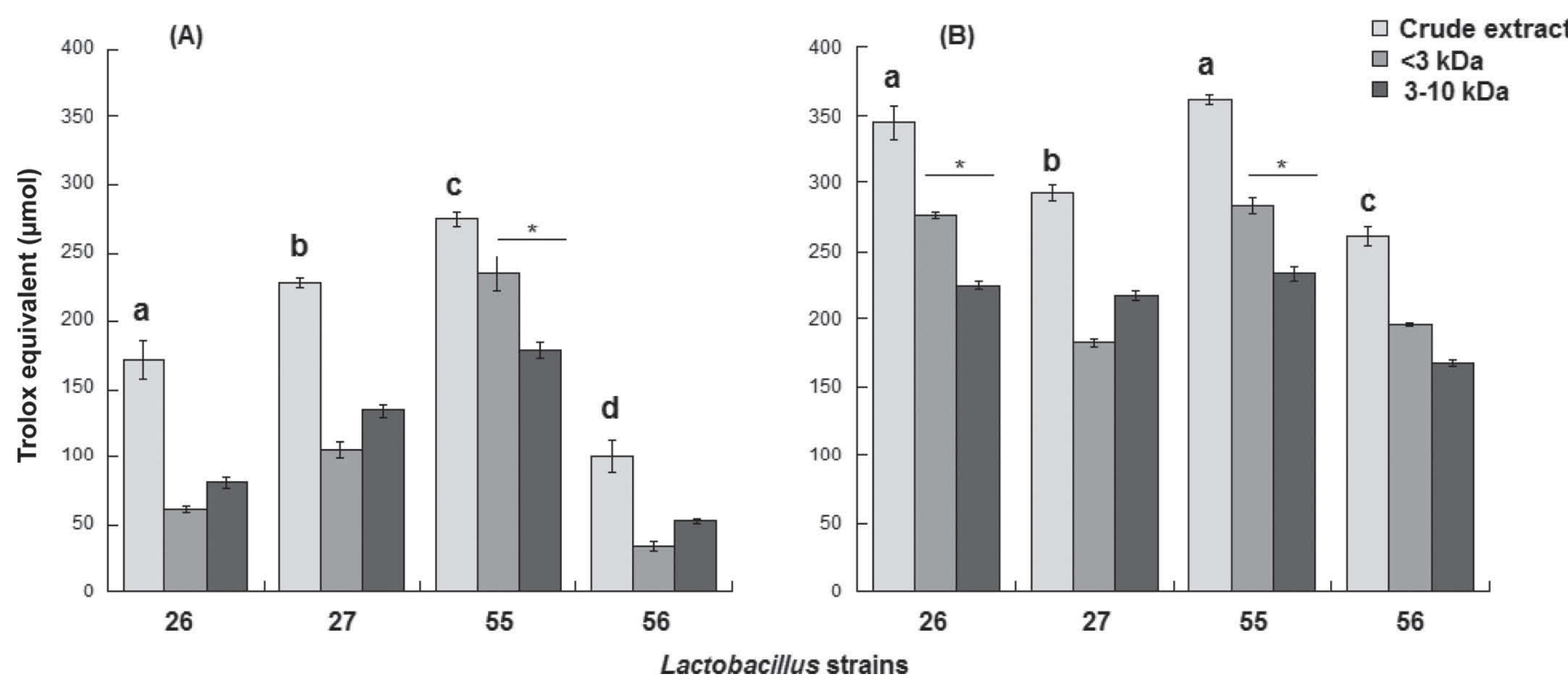

Figure 2. Antioxidant activity of crude extracts (CE) and peptide fractions ( $<3$ and $3-10 \mathrm{kDa})$ of fermented milk by specific Lactobacillus strains, determined by (A) 2,2'-azinobis(3-ethylbenzothiazoline)-6-sulphonic acid and (B) oxygen radical absorbance capacity methods. Different letters $(\mathrm{a}-\mathrm{d})$ on bars indicate statistical differences between $\mathrm{CE}(P<0.05)$, whereas an asterisk $(*)$ indicates statistical differences $(P<0.05)$ between fractions for the same strain. Data are average $( \pm \mathrm{SD})$ of triplicate samples, obtained in 3 independent assays.

of peptides released from yogurt water-soluble extracts was determined using the ABTS and 2,2-diphenyl-apicryhydrazyl methods by Aloğlu and Öner (2011). Those authors reported mean values of $7.697 \mathrm{mmol}$ of Trolox/g in commercial yogurts and $10.115 \mathrm{mmol}$ of Trolox/g in traditional yogurts. Because a practical procedure for evaluating antioxidant activity may vary in different respects, and in some cases activity is concluded based on a single antioxidant test mode, comparison of results from different studies is as difficult as it is to distinguish only one mechanism or compound involved in the antioxidant activity (Alam et al., 2013).

On the other hand, antioxidant capacity of fractions from fermented milks showed that $<3-\mathrm{kDa}$ fractions gave significantly $(P<0.05)$ higher $(234.1 \mu \mathrm{mol}$ of Trolox equivalents) capacity than 3 to $10 \mathrm{kDa}$ fractions $(210.3 \mu \mathrm{mol}$ of Trolox equivalents) in the ORAC method, whereas no statistical difference $(P>0.05)$ was observed for the values obtained by ABTS method in both $<3-\mathrm{kDa}(108.8 \mu \mathrm{mol}$ of Trolox equivalents) and 3 to $10 \mathrm{kDa}$ (111.4 $\mu \mathrm{mol}$ of Trolox equivalents) fractions. These results suggest that the low molecular weight fractions are best responsible for antioxidant capacity. Accordingly, Qian et al. (2011) demonstrated that the antioxidant capacity of low molecular weight fractions 1 to 3 and 3 to $5 \mathrm{kDa}$ were significantly higher $(P<0.05)$ than $<1$ and the 5 to $10 \mathrm{kDa}$ fractions from fermented milk with $L$. delbrueckii ssp. bulgaricus LB340. Furthermore, Irshad et al. (2015) assessed the antioxidant activity of bioactive peptides derived from bovine casein hydrolyzed using trypsin and pepsin at different time intervals. Their results showed that the $<1-\mathrm{kDa}$ fraction exhibited better antioxidant activity than the $10-\mathrm{kDa}$ fraction, which support the results of the present study.

\section{Antimicrobial Activity}

Our data showed that all CE assessed exhibited moderate antimicrobial activity against Escherichia coli, Staphylococcus aureus, Listeria innocua, Salmonella Typhimurium, and Salmonella Choleraesuis, which showed percentages of survival ranging from 48 to $76 \%$. Lactobacillus plantarum $26 \mathrm{CE}$ displayed the highest antimicrobial activity, particularly against $L$. innocua (Table 2); therefore, such CE was selected for further assays. In this regard, when L. plantarum 26 $\mathrm{CE}$ was adjusted to $\mathrm{pH} 6.8$ and subjected to proteolytic enzymes, most pathogens showed a significantly $(P<0.05)$ higher percentage of survival compared with L. plantarum $26 \mathrm{CE}$ untreated (Table 3). These results exclude possible inhibition effects attributed to organic acids and showed the proteinaceous nature of compounds associated with antimicrobial activity. These findings are in agreement with those previously reported by Atanasova et al. (2014) and Peres et al. (2014).

Peptide fractions from L. plantarum 26 showed no significant $(P<0.05)$ difference on antimicrobial activity against $E$. coli compared with crude extracts, which 
Table 2. Survival (expressed as percentage) of target bacteria exposed to crude extracts of fermented milk with Lactobacillus plantarum strains; data are average $( \pm \mathrm{SD})$ of triplicate samples, obtained in 3 independent assays

\begin{tabular}{|c|c|c|c|c|c|}
\hline $\begin{array}{l}\text { Strain, survival } \\
(\%)\end{array}$ & $\begin{array}{l}\text { Escherichia } \\
\text { coli }\end{array}$ & $\begin{array}{c}\text { Staphylococcus } \\
\text { aureus }\end{array}$ & $\begin{array}{l}\text { Listeria } \\
\text { innocua }\end{array}$ & $\begin{array}{c}\text { Salmonella } \\
\text { Typhimurium }\end{array}$ & $\begin{array}{c}\text { Salmonella } \\
\text { Choleraesuis }\end{array}$ \\
\hline $\begin{array}{l}26 \\
27 \\
55 \\
56\end{array}$ & $\begin{array}{l}55.32 \pm 1.02^{\mathrm{a}, \mathrm{A}} \\
69.64 \pm 2.80^{\mathrm{a}, \mathrm{B}} \\
72.45 \pm 2.82^{\mathrm{a}, \mathrm{B}} \\
62.75 \pm 0.98^{\mathrm{a}, \mathrm{AB}}\end{array}$ & $\begin{array}{l}58.81 \pm 2.00^{\mathrm{b}, \mathrm{A}} \\
71.77 \pm 2.50^{\mathrm{b}, \mathrm{B}} \\
76.27 \pm 2.40^{\mathrm{b}, \mathrm{B}} \\
69.83 \pm 1.98^{\mathrm{b}, \mathrm{B}}\end{array}$ & $\begin{array}{l}48.76 \pm 1.50^{\mathrm{a}, \mathrm{A}} \\
68.28 \pm 1.50^{\mathrm{b}, \mathrm{B}} \\
74.76 \pm 3.70^{\mathrm{b}, \mathrm{B}} \\
68.54 \pm 1.13^{\mathrm{b}, \mathrm{B}}\end{array}$ & $\begin{array}{l}60.58 \pm 3.45^{\mathrm{b}, \mathrm{A}} \\
76.27 \pm 1.30^{\mathrm{b}, \mathrm{B}} \\
76.27 \pm 1.30^{\mathrm{b}, \mathrm{B}} \\
69.84 \pm 1.53^{\mathrm{b}, \mathrm{B}}\end{array}$ & $\begin{array}{l}53.73 \pm 2.80^{\mathrm{ab}, \mathrm{A}} \\
74.04 \pm 0.98^{\mathrm{b}, \mathrm{B}} \\
75.20 \pm 2.90^{\mathrm{b}, \mathrm{B}} \\
68.90 \pm 3.23^{\mathrm{b}, \mathrm{B}}\end{array}$ \\
\hline
\end{tabular}

$\overline{\mathrm{a}, \mathrm{b}}$ Rows with common lowercase letters indicate no significant differences $(P<0.05)$ among target bacteria for each Lactobacillus strain.

${ }^{\mathrm{A}, \mathrm{B}}$ Columns with uppercase letters indicate no significant differences $(P<0.05)$ among Lactobacillus strain for each target strain.

suggest a strain-specific activity related to peptide fractions of molecular weight smaller than 3 and 3 to 10 $\mathrm{kDa}$. Conversely, peptide fractions displayed only minor inhibitory activity against the other targeted bacteria (Table 2). The lack of activity observed indicates that the $>10-\mathrm{kDa}$ fraction may also retain antimicrobial activity and was not improved by membrane filtration. In this sense, size-fraction studies dealing with milk-derived peptides have been undertaken to determine the nature of the antimicrobial activity. Collectively, these studies have documented the presence of low-molecular weight $(0.5-7 \mathrm{kDa})$ middle-molecular weight $(<30 \mathrm{kDa})$ antimicrobial peptides (Hayes et al., 2006; Benkerroum, 2010; Dziuba and Dziuba, 2014), which is consistent with our results; however, more studies are still needed to clarify relationship between peptide structure and antimicrobial activity, as well as to discard possible secondary activity by nonpeptide antimicrobial agents. Related reports have demonstrated that a hydrolyzed fraction with low molecular weight $(<3 \mathrm{kDa})$ obtained with ficin showed the highest antimicrobial activity than those exhibited by 3 to 5 and 5 to $10 \mathrm{kDa}$ fractions (Esmaeilpour et al., 2016). The data suggest that milk-derived bioactive peptides of low molecular weight obtained by microbial fermentation could be employed as natural antimicrobial agents.

It has been reported that the mechanisms of action of antimicrobial peptides is dependent on their AA composition as well as their structure and physicochemical characteristics (Clare et al., 2003; Akalin, 2014; Dziuba and Dziuba, 2014). Furthermore, some studies suggest that antimicrobial peptides may act by inhibiting DNA, RNA, and protein biosynthesis or by establishing an electrostatic bonding between the peptide and bacterial membrane components (the most dominant mechanism), thereby forming transient transmembrane channels that alter the membrane permeability (Zasloff, 2002; Reddy et al., 2004; Park et al., 2008). This later mechanism was seen here by simultaneous counterstaining of intact L. innocua cells (green-labeled) and L. innocua cells with damaged membranes (red-labeled) after treatment with either L. plantarum 26 peptide fractions of $<3$ (Figure $3 \mathrm{~b}$ ) or 3 to $10 \mathrm{kDa}$ (Figure 3c). Nontreated bacteria (control) showed bright green fluorescence, although traces of red-labeled bacteria were also observed, which presumably correspond to dead cells present in culture at the harvest (Figure 3a).

Overall, the crude extracts and peptide fractions $(<3$ or $3-10 \mathrm{kDa})$ assessed here exhibited anti-inflammatory, antihemolytic, antioxidant, antimutagenic, and antimicrobial activities to different extents, with crude extracts slightly more active than peptide fractions. Particularly, L. plantarum 55 crude extract or their fractions showed the higher anti-inflammatory, antihemolytic, and antioxidant activity. In this sense, milk-derived multifunctional peptides, such as lactoferrin, casein-derived phosphopeptides, and chymotryptic peptides, produced as a result of the hydrolytic action

Table 3. Survival (expressed as percentage) of target bacteria exposed to both crude extracts (CE) adjusted to $\mathrm{pH} 6.8$ and subjected to proteolytic enzymes, and peptide fractions $(<3$ and $3-10 \mathrm{kDa})$ of Lactobacillus plantarum 26; data are average $( \pm \mathrm{SD})$ of triplicate samples, obtained in 3 independent assays

\begin{tabular}{|c|c|c|c|c|c|}
\hline Strains survival (\%) & $\begin{array}{l}\text { Escherichia } \\
\text { coli }\end{array}$ & $\begin{array}{c}\text { Staphylococcus } \\
\text { aureus }\end{array}$ & $\begin{array}{l}\text { Listeria } \\
\text { innocua }\end{array}$ & $\begin{array}{c}\text { Salmonella } \\
\text { Typhimurium }\end{array}$ & $\begin{array}{c}\text { Salmonella } \\
\text { Choleraesuis }\end{array}$ \\
\hline $\mathrm{CE}$ & $59.71 \pm 5.53^{\mathrm{a}, \mathrm{A}}$ & $57.32 \pm 3.25^{\mathrm{a}, \mathrm{A}}$ & $42.78 \pm 3.45^{\mathrm{b}, \mathrm{A}}$ & $50.98 \pm 3.22^{\mathrm{c}, \mathrm{A}}$ & $48.57 \pm 3.25^{\mathrm{c}, \mathrm{A}}$ \\
\hline $\mathrm{CE}+$ proteinase $\mathrm{K}$ & $72.84 \pm 3.22^{\mathrm{a}, \mathrm{B}}$ & $75.91 \pm 4.03^{\mathrm{a}, \mathrm{B}}$ & $81.13 \pm 0.99^{\mathrm{b}, \mathrm{B}}$ & $84.99 \pm 2.14^{\mathrm{b}, \mathrm{B}}$ & $72.21 \pm 2.33^{\mathrm{a}, \mathrm{B}}$ \\
\hline $\mathrm{CE}$ with adjusted $\mathrm{pH}(6.8)$ & $64.15 \pm 0.99^{\mathrm{a}, \mathrm{C}}$ & $63.16 \pm 1.33^{\mathrm{a}, \mathrm{C}}$ & $61.60 \pm 1.25^{\mathrm{a}, \mathrm{C}}$ & $61.01 \pm 2.01^{\mathrm{a}, \mathrm{C}}$ & $49.71 \pm 2.11^{\mathrm{b}, \mathrm{A}}$ \\
\hline $3-10 \mathrm{kDa}$ & $54.54 \pm 3.71^{\mathrm{a}, \mathrm{A}}$ & $77.54 \pm 1.21^{\mathrm{b}, \mathrm{D}}$ & $68.56 \pm 2.21^{\mathrm{c}, \mathrm{C}}$ & $82.05 \pm 1.28^{\mathrm{b}, \mathrm{B}}$ & $92.38 \pm 1.54^{\mathrm{b}, \mathrm{D}}$ \\
\hline$<3 \mathrm{kDa}$ & $57.41 \pm 2.87^{\mathrm{a}, \mathrm{A}}$ & $67.54 \pm 2.12^{\mathrm{b}, \mathrm{C}}$ & $72.76 \pm 1.34^{\mathrm{b}, \mathrm{D}}$ & $62.60 \pm 3.00^{\mathrm{a}, \mathrm{C}}$ & $79.38 \pm 0.98^{\mathrm{c}, \mathrm{B}}$ \\
\hline
\end{tabular}

\footnotetext{
${ }^{\mathrm{a}-\mathrm{d}}$ Rows with common lowercase letters indicate no significant differences $(P<0.05)$ among target bacteria for each treatment.

${ }^{\mathrm{A}-\mathrm{D}}$ Columns with common uppercase letters indicate no significant differences $(P<0.05)$ among treatments for each target strain $(P<0.05)$.
} 

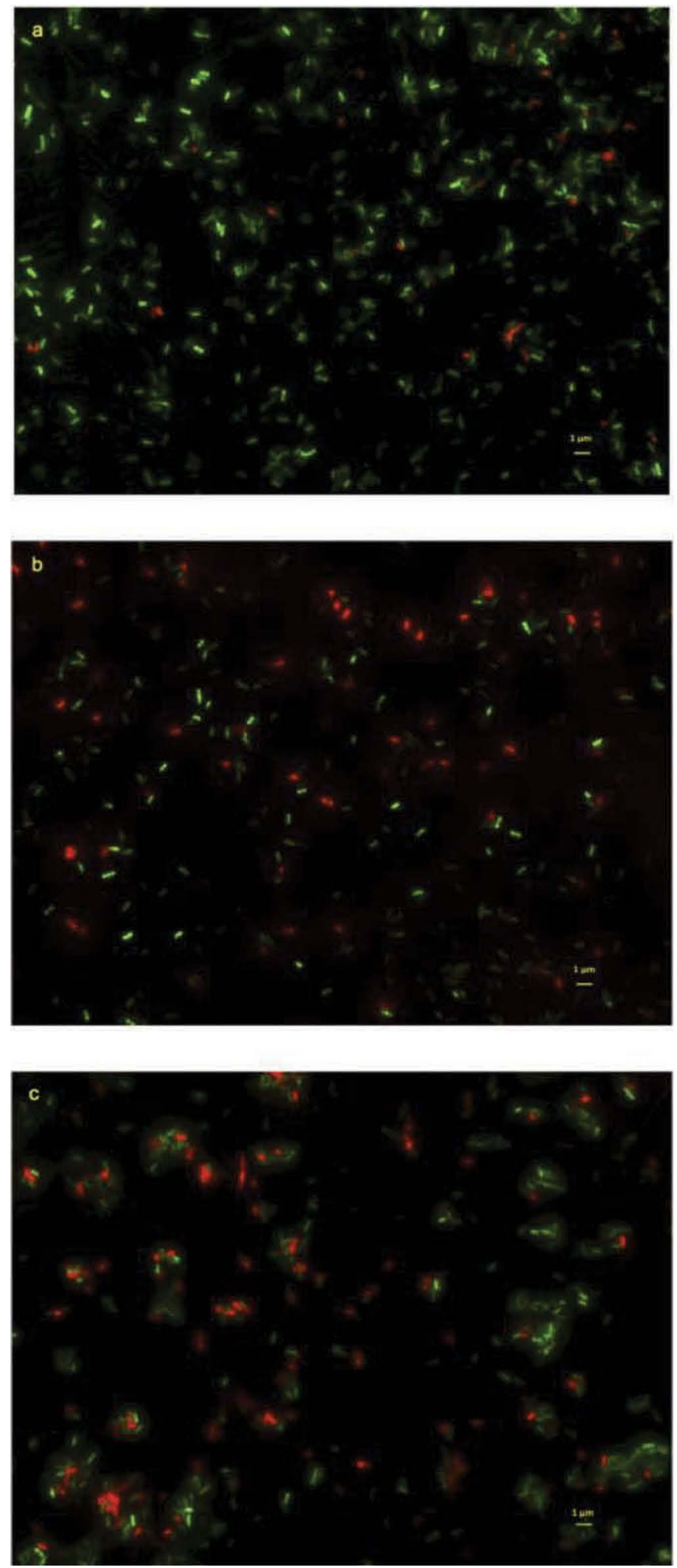

Figure 3. Representative fluorescent micrographs of Listeria innocua double labeled with carboxyfluorescein diacetate succinimidyl ester (intact Listeria innocua cells green-labeled) and propidium iodide (membrane-damage Listeria innocua cells red-labeled). Cells without treatment (a) and after treatment with Lactobacillus plantarum 26 peptide fraction $<3 \mathrm{kDa}$ (b) or $3-10 \mathrm{kDa}$ (c). All images were taken using immersion objective $(100 \times)$. Color version available online. of digestive proteases (i.e., pepsin, trypsin, chymotrypsin), and their functionalities (e.g., antibacterial, antifungal, antiallergic, anticancer, antihypertensive, cytomodulatory, antioxidant) have previously been reported in the literature (Srinivas and Prakash 2010; Sistla, 2013; Mandal et al., 2014; Agyei et al., 2015). However, to the best of our knowledge, few studies have described the multifunctional role of peptides derived from fermented milk by the action of specific Lactobacillus strains (Qian et al., 2011; Elfahri et al., 2014).

\section{CONCLUSIONS}

The present study reports the multiple combined activities, namely anti-inflammatory, antihemolytic, antioxidant, antimutagenic, and antimicrobial, of crude extracts or their fractions from milks fermented with specific Lactobacillus strains. In this study we observed that crude extracts had greater activity either than $<3$ or 3 to $10 \mathrm{kDa}$ peptide fractions in most of the assays. The results indicate that these multifunctional peptides, particularly those derived from L. plantarum 55, possess valuable potential as dietary bioactive compounds for the development of biotechnological products for the nutraceutical industry. However, further studies are needed to determine their precise mechanism of action, to clarify the relationship with peptide structure activity, and to validate the biological activities in vivo using animal models or clinical trials.

\section{ACKNOWLEDGMENTS}

The authors thank the National Council for Science and Technology (CONACyT) of Mexico for graduate scholarships for authors Aguilar-Toalá and SantiagoLopez.

\section{REFERENCES}

Agyei, D., R. Potumarthi, and M. K. Danquath. 2015. Food-derived multifunctional bioactive proteins and peptides: Sources and production. Pages 483-506 in Biotechnology of Bioactive Compounds. Sources and Applications. V. K. Gupta and M. G. Tuohy, ed. Wiley Blackwell, Oxford, UK

Akalin, A. S. 2014. Dairy-derived antimicrobial peptides: Action mechanisms, pharmaceutical uses and production proposals. Trends Food Sci. Technol. 36:79-95. https://doi.org/10.1016/j. tifs.2014.01.002.

Alam, M. N., N. J. Bristi, and M. Rafiquzzaman. 2013. Review on in vivo and in vitro methods evaluation of antioxidant activity. Saudi Pharm. J. 21:143-152. https://doi.org/10.1016/j.jsps.2012.05.002.

Albano, H., S. D. Todorov, C. A. van Reenen, T. Hogg, L. M. T. Dicks, and P. Texeira. 2007. Characterization of two bacteriocins produced by Pediococcus acidilactici isolated from "Alheira", a fermented sausage traditionally produced in Portugal. Int. J. Food Microbiol. 116:239-247. https://doi.org/10.1016/j.ijfoodmicro.2007.01.011.

Aloğlu, H. S., and Z. Öner. 2011. Determination of antioxidant activity of bioactive peptide fractions obtained from yogurt. J. Dairy Sci. 94:5305-5314. https://doi.org/10.3168/jds.2011-4285. 
Atanasova, J., P. Moncheva, and I. Ivanova. 2014. Proteolytic and antimicrobial activity of lactic acid bacteria grown in goat milk. Biotechnol. Biotechnol. Equip. 28:1073-1078. https://doi.org/10.1 080/13102818.2014.971487.

Benkerroum, N. 2010. Antimicrobial peptides generated from milk proteins: A survey and prospects for application in the food industry. A review. Int. J. Dairy Technol. 63:320-338. https://doi. org/10.1111/j.1471-0307.2010.00584.x.

Cadée, J. A., C. Y. Chang, C. W. Chen, C. N. Huang, S. L. Chen and C. K. Wang. 2007. Bovine casein hydrolysate (C12 peptide) reduces blood pressure in prehypertensive subjects. Am. J. Hypertens. 20:1-5. https://doi.org/10.1016/j.amjhyper.2006.06.005.

Chandra, S., P. Chatterjee, P. Dey, and S. Bhattacharya. 2012. Evaluation of in vitro anti-inflammatory activity of coffee against the denaturation of protein. Asian Pac. J. Trop. Biomed. 2:178-180. https://doi.org/10.1016/S2221-1691(12)60154-3.

Chatterjee, P., S. Chandra, P. Dey, and S. Bhattachayra. 2012. Evaluation of anti-inflammatory effects of green tea and black tea: A comparative in vitro study. J. Adv. Pharm. Technol. Res. 3:136138. https://doi.org/10.4103/2231-4040.97298.

Clare, D. A., G. L. Catignani, and H. E. Swaisgood. 2003. Biodefense properties of milk: The role of antimicrobial proteins and peptides. Curr. Pharm. Des. 9:1239-1255. https://doi. org/10.2174/1381612033454874.

Da Silva, E., M. Foley, A. R. Dluzeski, L. J. Murray, R. F. Anders, and L. Tilley. 1994. The Plasmodium falciparum protein RESA interacts with the erythrocyte cytoskeleton and modifies erythrocyte thermal stability. Mol. Biochem. Parasitol. 66:59-69. https://doi. org/10.1016/0166-6851(94)90036-1.

Dasari, S., R. N. D. Shouri, R. Wudayagiri, and L. Valluru. 2014. Antimicrobial activity of Lactobacillus against microbial flora of cervicovaginal infections. Asian Pac. J. Trop. Dis. 4:18-24. https:// doi.org/10.1016/S2222-1808(14)60307-8.

Dixon, K., and E. Kopras. 2004. Genetic alterations and DNA repair in human carcinogenesis. Semin. Cancer Biol. 14:441-448. https:// doi.org/10.1016/j.semcancer.2004.06.007.

Donkor, O. N., A. Henriksson, T. K. Singh, T. Vasiljevic, and N. P. Shah. 2007. ACE-inhibitory activity of probiotic yoghurt. Int. Dairy J. 17:1321-1331.

Dziuba, B., and M. Dziuba. 2014. New milk protein-derive peptides with potential antimicrobial activity: An approach based on bioinformatic studies. Int. J. Mol. Sci. 15:14531-14545. https://doi. org/10.3390/ijms150814531.

Ebringer, L., M. Ferencik, and J. Krajcovic. 2008. Beneficial health effects of milk and fermented dairy products - Review. Folia Microbiol. (Praha) 53:378-394. https://doi.org/10.1007/s12223-0080059-1.

Elfahri, K. R., O. N. Donkor, and T. Vasiljevic. 2014. Potential of novel Lactobacillus helveticus strains and their cell wall bound proteases to release physiologically active peptides from milk proteins. Int. Dairy J. 38:37-46. https://doi.org/10.1016/j.idairyj.2014.03.010.

Eliassen, L. T., G. Berge, A. Leknessud, M. Wikman, I. Lindin, and C Lokke. 2006. The antimicrobial peptide, lactoferricinn B is cytotoxic to neuroblastoma cells in vitro and inhibits xenograft growth in vivo. Int. J. Cancer. 119:493-500. https://doi.org/10.1002/ ijc. 21886 .

Epand, R. M., A. Starfford, B. Leon, P. E. Lock, E. M. Tytler, J. P. Segrestm, and G. M. Anantharamaiah. 1994. HDL and apoliprotein A-I protect erythrocytes against the generation of procoagulant activity. Arterioscler. Thromb. 14:1775-1783.

Esmaeilpour, M., M. R. Ehsani, M. Aminlari, S. Shekarforoush, and E. Hoseini. 2016. Antimicrobial activity of peptides derived from enzymatic hydrolysis of goat milk caseins. Comp. Clin. Pathol. 25:599-605.

Espeche Turbay, M. B., A. de Moreno de LeBlanc, G. Perdigón, G. Savoy de Giori, and E. M. Hebert. 2012. $\beta$-casein hydrolysate generated by the cell envelope-associated proteinase of Lactobacillus delbrueckii ssp. lactis CRL 581 protects against trinitrobenzene sulfonic acid-induced colitis in mice. J. Dairy Sci. 95:1108-1118. https://doi.org/10.3168/jds.2011-4735.
FitzGerald, R. J., and B. A. Murray. 2006. Bioactive peptides and lactic fermentations. Int. J. Dairy Technol. 59:118-125. https:// doi.org/10.1111/j.1471-0307.2006.00250.x.

Gershfeld, N. L., and M. Murayama. 1988. Thermal instability of red blood cell membrane bilayers: temperature dependence of hemolysis. J. Membr. Biol. 101:67-72. https://doi.org/10.1007/ BF01872821.

Grant, N. H., H. E. Alburn, and C. Kryzanauskas. 1970. Stabilization of serum albumin by anti-inflammatory drugs. Biochem. Pharmacol. 19:715-722.

Hartmann, R., and H. Meisel. 2007. Food-derived peptides with biological activity: from research to food applications. Curr. Opin. Biotechnol. 18:163-169. https://doi.org/10.1016/j.copbio.2007.01.013.

Hayes, M., R. P. Ross, G. F. Fitzgerald, C. Hill, and C. Stanton. 2006. Casein-derived antimicrobial peptides generated by Lactobacillus acidophilus DPC6026. Appl. Environ. Microbiol. 72:2260-2264. / https://doi.org/10.1128/AEM.72.3.2260-2264.2006.

Hernández-Ledesma, B., B. Miralles, L. Amigo, M. Ramos, and I Recio. 2005. Identification of antioxidant and ACE-inhibitory peptides in fermented milk. J. Sci. Food Agric. 85:1041-1048. https:// doi.org/10.1002/jsfa.2063.

Hosoda, M., H. Hashimoto, H. Morita, M. Chiba, and A. Hosono. 1992. Antimutagenicity of milk cultured with lactic acid bacteria against $\mathrm{N}$-methyl-N'-nitro-N-nitrosoguanidine. J. Dairy Sci. 75:976-981. https://doi.org/10.3168/jds.S0022-0302(92)77839-4.

Irshad, I., A. Kanekanian, A. Peters, and T. Masud. 2015. Antioxidant activity of bioactive peptides derived from bovine casein hydrolysate fractions. J. Food Sci. Technol. 52:231-239.

Jakubowicz, D., and O. Froy. 2013. Biochemical and metabolic mechanisms by which dietary whey protein may combat obesity and Type 2 diabetes. J. Nutr. Biochem. 24:1-5. https://doi.org/10.1016/j. jnutbio.2012.07.008.

Joshi, I., S. Sudhakar, and R. Abdul-Nazeer. 2016. Anti-inflammatory properties of bioactive peptide derived from gastropod influenced by enzymatic hydrolysis. Appl. Biochem. Biotechnol. https://doi. org/10.1007/s12010-016-2156-y.

Kendrick, B., T. Li, and B. S. Chang. 2002. Physical stabilization of proteins in aqueous solution. Page 203 in Rational Design of Stable Protein Formulations: Theory and Practice, Vol. 13. J. F. Carpenter and M. C. Manning, ed. Kluwer Academic/Plenum Publishers, New York, NY.

Khan, M. A., H. Khan, A. Rauf, and T. B. Hadda. 2015. Inhibition of thermal induced protein denaturation of extract/fractions of Withania somnifera and isolated withanolides. Nat. Prod. Res. 29:2318-2321. https://doi.org/10.1080/14786419.2015.1007138.

Korhonen, H. 2009. Milk-derived bioactive peptides: From science to applications. J. Funct. Foods 1:177-187. https://doi.org/10.1016/j. jff.2009.01.007.

Li, H., N. Prairie, C. C. Udenigwe, A. P. Adebiyi, P. S. Tappia, H. M. Aukema, P. J. H. Jones, and R. E. Aluko. 2011. Blood pressure lowering effect of a pea protein hydrolysate in hypertensive rats and humans. J. Agric. Food Chem. 59:9854-9860. https://doi. org/10.1021/jf201911p.

Liu, J. R., M. J. Chen, and C. W. Lin. 2005. Antimutagenic and antioxidant properties of milk-kefir and soy-milk kefir. J. Agric. Food Chem. 53:2467-2474. https://doi.org/10.1021/jf048934k.

López-Meza, J. E., A. Ochoa-Zarzosa, J. E. Barboza-Corona, and D. K. Bideshi. 2015. Antimicrobial peptides: Current and potential applications in biomedical therapies. BioMed Res. Int. 2015:367243. https://doi.org/10.1155/2015/367243.

Mandal, S. M., R. Bharti, W. F. Porto, S. S. Gauri, M. Mandal, O. L. Franco, and A. K. Ghosh. 2014. Identification of multifunctional peptides from human milk. Peptides 56:84-93. https://doi. org/10.1016/j.peptides.2014.03.017.

Manders, R. J. F., S. F. E. Praet, R. C. R. Meex, R. Koopman, A. L. de Roos, A. J. M. Wagenmakers, W. H. M. Saris, and L. J. C. van Loon. 2006. Protein hydrolysate/leucine co-ingestion reduces the prevalence of hyperglycemia in type 2 diabetic patients. Diabetes Care 29:2721-2722. https://doi.org/10.2337/dc06-1424.

Manukumar, H.M.G., and S. Umesha. 2015. Assessment of membrane stabilizing activity from honey an in vitro approach. Acta Sci. 
Pol. Technol. Aliment. 14:85-90. https://doi.org/10.17306/J. AFS.2015.1.10.

Mariam, S. H., N. Zegeye, T. Tariku, E. Andargie, N. Edalafer, and A. Aseffa. 2014. Potential of cell-free supernatants from cultures of selected lactic acid bacteria and yeast obtained from local fermented foods as inhibitors of Listeria monocytogenes, Salmonella spp. and Staphylococcus aureus. BMC Res. Notes 7:606 https:// doi.org/10.1186/1756-0500-7-606.

Matar, C., J. C. LeBlanc, L. Martin, and G. Perdigon. 2003. Biologically active peptides released from fermented milk: role and functions. Pages 177-201 in Handbook of Fermented Functional Foods. T. Farnworth, ed. CRC Press, Boca Raton, FL.

Mizushima, Y., and M. Kobayashi. 1968. Interaction of anti-inflammatory drugs with serum proteins, especially with some biologically active proteins. J. Pharm. Pharmacol. 20:169-173. https://doi. org/10.1111/j.2042-7158.1968.tb09718.x.

Mohanty, D. P., P. Tripathy, S. Mohapatra, and D. P. Samantaray. 2014. Bioactive potential assessment of antibacterial peptide produced by Lactobacillus isolated from milk and milk products. Int. J. Curr. Microbiol. Appl. Sci. 3:72-80.

Mortelmans, K., and E. Zeiger. 2000. The Ames salmonella/microsome mutagenicity assay. Mutat. Res. 455:29-60. https://doi. org/10.1016/S0027-5107(00)00064-6.

Obruca, S., P. Sedlacek, F. Mravec, O. Samek, and I. Marova. 2015. Evaluation of 3-hydroxybutyrate as an enzyme-protective agent against heating and oxidative damage and its potential role in stress response of poly(3-hydroxybutyrate) accumulating cells. Appl. Microbiol. Biotechnol. 100:1365-1376. http://dx.doi.org/ https://doi.org/10.1007/s00253-015-7162-4.

Ou, B., M. Hampsch-Woodill, and R. L. Prior. 2001. Development and validation of an improved oxygen radical absorbance capacity assay using fluorescein as the fluorescent probe. J. Agric. Food Chem. 49:4619-4626. https://doi.org/10.1021/jf010586o.

Park, S. C., M. H. Kim, M. A. Hossain, S. Y. Shin, Y. Kim, L. Stella, J. D. Wade, Y. Park, and K. S. Hahm. 2008. Amphipathic $\alpha$-helical peptide, HP (2-20), and its analogues derived from Helicobacter pylori: pore formation mechanism in various lipid compositions. Biochim. Biophys. Acta 1778:229-241.

Pei, X., X. Guo, R. Copper, S. Bhattacharjee, K. Haldar, W. Gratzer, N. Mohandas, and X. An. 2007. The ring-infected erythrocyte surface antigen (RESA) of Plasmodium falciparum stabilizes spectrin tetramers and suppresses further invasion. Blood 110:1036-1042.

Peres, C. M., M. Alvez, A. Hernandez-Mendoza, L. Moreira, S. Silva, M. R. Bronze, L. Vilas-Boas, C. Peres, and F. X. Malcata. 2014. Novel isolates of lactobacilli from fermented Portuguese olive as potential probiotics. LWT Food Sci. Technol. (Campinas) 59:234246. https://doi.org/10.1016/j.lwt.2014.03.003.

Prior, R. L., X. L. Wu, and K. Schaich. 2005. Standardized methods for the determination of antioxidant capacity and phenolics in foods and dietary supplements. J. Agric. Food Chem. 53:42904302. https://doi.org/10.1021/jf0502698.

Pripp, A. H. 2008. Effect of peptides derived from food proteins on blood pressure: A meta-analysis of randomized controlled trials. Food Nutr. Res. 52:1-9. https://doi.org/10.3402/fnr.v52i0.1641.

Qian, B., M. Xing, L. Cui, Y. Deng, Y. Xu, M. Huang, and S. Zhang. 2011. Antioxidant, antihypertensive, and immunomodulatory activities of peptide fractions from fermented skim milk with Lactobacillus delbrueckii ssp. bulgaricus LB340. J. Dairy Res. 78:72-79. https://doi.org/10.1017/S0022029910000889.

Rani, A. A., S. M. J. Punitha, and M. Rema. 2014. Anti-inflammatory activity of flower extract of Cassia auriculata- an in vitro study. Int. Res. J. Pharm. Appl. Sci. 4:57-60.

Re, R., N. Pellegrini, A. Proteggente, A. Pannala, M. Yang, and C. Rice-Evans. 1999. Antioxidant activity applying an improved ABTS radical cation decolorization assay. Free Radic. Biol. Med. 26:1231-1237. https://doi.org/10.1016/S0891-5849(98)00315-3.

Reddy, K. V. R., R. D. Yedery, and C. Aranha. 2004. Antimicrobial peptides: Premises and promises. Int. J. Antimicrob. Agents 24:536-547. https://doi.org/10.1016/j.ijantimicag.2004.09.005.

Roy, M. K., Y. Kuwabara, K. Hara, Y. Watanabe, and Y. Tamai. 2002. Peptides from the N-terminal end of bovine lactoferrin induce apoptosis in human leukemic (HL60) cells. J. Dairy Sci. 85:20652074. https://doi.org/10.3168/jds.S0022-0302(02)74284-7.

Sah, B. N. P., T. Vasiljevic, S. Mckechnie, and O. N. Donkor. 2014. Effect of probiotics on antioxidant and antimutagenic activities of crude peptide extract from yogurt. Food Chem. 156:264-270. https://doi.org/10.1016/j.foodchem.2014.01.105.

Sarac, N. 2015. Antioxidant, mutagenic, and antimutagenic activities of Tragopogon longirostis var. longirostis, an edible wild plant in Turkey. Indian J. Pharmacol. 47:414-418.

Saso, L., and B. Silvestrini. 2001. Antidenaturant drugs for cataract and other condensation diseases. Med. Hypotheses 56:114-120. https://doi.org/10.1054/mehy.2000.1128.

Seidler, N. W., and G. S. Yeargans. 2002. Effects of thermal denaturation on protein glycation. Life Sci. 70:1789-1799. https://doi. org/10.1016/S0024-3205(02)01474-1.

Seppo, L., T. Jauhiainen, T. Poussa, and R. Korpela. 2003. A fermented milk high in bioactive peptides has a blood pressure-lowering effect in hypertensive subjects. Am. J. Clin. Nutr. 77:326-330.

Shinde, U. A., A. S. Phadke, A. M. Nair, A. A. Mumgantiwar, V. J. Dikshit, and M. N. Saraf. 1999. Membrane stabilizing activity- a possible mechanism of action for the anti-inflammatory activity of Cedrus deora wood oil. Fitoterapia 70:251-257. https://doi. org/10.1016/S0367-326X(99)00030-1.

Słoczyńska, K., B. Powroznik, E. Pekala, and A. M. Waszkielewicz. 2014. Antimutagenic compounds and their possible mechanism of action. J. Appl. Genet. 55:273-285. https://doi.org/10.1007/ s13353-014-0198-9.

Sowemimo-Coker, S. O. 2002. Red blood cell hemolysis processing. Transfus. Med. Rev. 16:46-60. https://doi.org/10.1053/ tmrv.2002.29404.

Sistla, S. 2013. Structure-activity relationship of $\alpha$ s-casein peptides with multifunctional biological activities. Mol. Cell. Biochem. 384:29-38. https://doi.org/10.1007/s11010-013-1778-4.

Srinivas, S., and V. Prakash. 2010. Bioactive peptides from bovine milk $\alpha$-casein: Isolation, characterization and multifunctional properties. Int. J. Pept. Res. Ther. 16:7-15. https://doi.org/10.1007/ s10989-009-9196-x.

Tanev-Ivanov, I. 2014. Role of plasma membrane in the thermal hemolysis of mammalian erythrocytes. Medicine 4:76-82.

Townsend, R. R., C. B. McFadden, V. Ford, and J. A. Cadée. 2004. A randomized, double-blind, placebo-controlled trial of casein protein hydrolysate (C12 peptide) in human essential hypertension. Am. J. Hypertens. 17:1056-1058. https://doi.org/10.1016/j. amjhyper.2004.06.018.

van Boekel, M. A. J. S., C. N. J. M. Weerens, A. Holstra, C. E. Scheidtweiler, and G. M. Alink. 1993. Antimutagenic effects of casein and its digestion products. Food Chem. Toxicol. 31:731-737. https://doi.org/10.1016/0278-6915(93)90144-N.

Virtanen, T., A. Pihlanto, S. Akkanen, and H. Korhonen. 2007. Development of antioxidant activity in milk whey during fermentation with lactic acid bacteria. J. Appl. Microbiol. 102:106-115. https:// doi.org/10.1111/j.1365-2672.2006.03072.x.

Williams, L. A. D., A. O'Connar, L. Latore, O. Dennis, S. Ringer, J. A. Whittaker, J. Conrad, B. Vogler, H. Rosner, and W. Kraus. 2008. The in vitro anti-denaturation effects induced by natural products and non-steroidal compounds in heat treated (immunogenic) bovine serum albumin is proposed as a screening assay for the detection of anti-inflammatory compounds, without the use of animals, in the early stages of the drug discovery process. West Indian Med. J. 57:327-331.

Yamamura, S., H. Morishima, T. Kumano-Go, N. Suganuma, H. Matsumoto, H. Adachi, Y. Sigedo, A. Mikami, T. Kai, A. Masuyama, T. Takano, Y. Sugita, and M. Takeda. 2009. The effect of Lactobacillus helveticus fermented milk on sleep and health perception in elderly subjects. Eur. J. Clin. Nutr. 63:100-105. https://doi. org/10.1038/sj.ejcn.1602898.

Zasloff, M. 2002. Antimicrobial peptides of multicellular organisms. Nature 415:389-395. https://doi.org/10.1038/415389a. 